\section{Environmental indicators of intra-urban hetererogeneity}

\author{
Indicadores ambientais para detectar \\ heterogeneidade intraurbana
}

Indicadores ambientales para detectar
la heterogeneidad intra-urbana
Rita Franco Rego 1

Veronica Cadena Lima ${ }^{1}$

Ana Cerqueira Lima 1

Mauricio L. Barreto 2

Matildes S. Prado 2

Agostino Strina 2

\footnotetext{
${ }_{1}$ Faculdade de Medicina da Bahia, Universidade Federal da Bahia, Salvador, Brasil. 2 Instituto de Saúde Coletiva, Universidade Federal da Bahia, Salvador, Brasil.

Correspondence R. F. Rego Programa de Pós-graduação em Saúde Ambiente e Trabalho, Faculdade de Medicina da Bahia, Universidade Federal da Bahia.

Pça. XV de Novembro $s / n$ Salvador, BA 40025-010, Brasil ritarego@ufba.br
}

\begin{abstract}
A large number of human diseases are related to poor access to water and sewer systems, inadequate solid waste management and deficient storm water drainage. The goal of this study was to formulate environmental sanitation indicators and classify sanitation conditions in specific sewer basins and their respective neighborhoods. The database used contains information on the following sanitation components in these areas: water supply, sewer systems, urban drainage, road pavement, building typology and public cleaning. Data was analyzed using cluster analysis. The key variable of each component was identified, and eight sewer basins and twenty-three neighborhoods were classified into the following categories: good, regular, and poor. The use of environmental sanitation indicators allows decision makers to identify critical areas and define priorities for improving environmental sanitation conditions.
\end{abstract}

Environmental Indicators; Sanitation; Environmental Health

\section{Resumo}

Várias patologias que acometem os seres humanos estão ligadas à deficiência de acesso a água e serviços de esgotamento sanitário, inadequado manejo de resíduos sólidos e deficiência do sistema de drenagem das águas pluviais. Este estudo buscou desenvolver indicadores sanitário ambientais e classificar áreas intraurbanas. Utilizou-se uma base de dados contendo informações sobre: abastecimento de água, sistema de esgoto, drenagem e limpeza urbana, pavimentação e tipologia construtiva referentes a bacias de esgotamento sanitário e áreas sentinela. Foi aplicada a técnica de analise de cluster. Identificou-se a variável que melhor representava cada componente, e oito bacias de esgotamento e vinte e três áreas sentinelas foram classificadas em três categorias: boa, regular e insatisfatória. O uso de indicador sanitário ambiental permitiu a identificação de áreas críticas e o estabelecimento de prioridades de investimentos para as melhorias sanitário ambientais.

Indicadores Ambientais; Saneamento; Saúde Ambiental 


\section{Introduction}

The evaluation of urban environmental quality is a challenging task for those involved in the environmental health field. The formulation of environmental indicators is fundamental to the assessment of environmental quality; thus environmental indicators are crucial to the formulation and implementation of public policies. Studies show that the provision of adequate basic sanitation services (a safe water supply and solid waste, sewage and stormwater management) plays a crucial role in public health 1,2 and is paramount to improving people's health and quality of life. The consideration of heterogeneity between urban areas through the identification of "intra-urban differentials" is also essential to the assessment process.

A United Nations report ${ }^{3}$ highlights increasing urbanization and associated environmental problems in several countries throughout the world. A report recently published in Brazil evaluates compliance with the Millennium Development Goals (MDGs), including target 7 (Ensuring Environmental Sustainability) and goals 10 to 14 which address issues related to basic sanitation. The report highlights: "Another important challenge is to improve the quantity and quality of evaluations of policies and programs and the existing information on housing conditions and sanitation in Brazil, since the sources available from the National Household Sample Survey and Census provide limited information about these issues" 4. Poor basic sanitation and housing conditions are an environmental risk to human health and overcoming this problem is a major challenge, especially in developing countries that seek to meet the development goals contemplated in the Millennium Declaration 5.

The formulation of environmental sanitation indicators and the identification of intra-urban differentials are essential to achieving the Millennium Goals. Furthermore, these indicators are extremely useful environmental and epidemiological surveillance tools and an important input to guide resource allocation plans and programs.

Several environmental risk factors may contribute to the occurrence of diseases and disorders in human populations 2,6. Pruss-Ustun and Corvalán 2 estimated that around $24 \%$ of worldwide illnesses can be traced back to environmental risk factors. The authors observed that 85 out of the 102 major diseases and injuries classified by the World Health Organization (WHO) in a report published in 2004 can be attributed to environmental risk factors. In particular, an estimated $94 \%$ of the incidence of diarrhea is attributable to environmental factors.
Epidemiological studies indicate that incidence rates of waterborne diseases such as diarrhea ${ }^{7}$, cholera ${ }^{8}$, hepatitis ${ }^{9}$, intestinal parasites 10 and typhoid fever are highest in urban locations characterized by low or insufficient coverage of basic sanitation services 11, 12 .

The present study is part of a series of studies developed under the Epidemiological Impact Assessment of the Todos os Santos Bay Environmental Sanitation Program (the Bahia Azul Program), a government program that focused on extending the sewer network funded by the InterAmerican Development Bank and implemented by the Bahia State Water and Sanitation Company (EMBASA). The present study comprises a subproject implemented during the Bahia Azul Program monitoring process to evaluate its environmental impact using environmental sanitation variables. One of the goals of the study was to assess intra-urban differentials through the classification of sanitation conditions in specific sewer basins and their respective neighborhoods located in the capital of the State of Bahia, Salvador. The study also carried out a quantitative analysis of the environmental sanitation components using a reduced number of variables and a low cost and simple methodology.

The Bahia Azul Program's limited resources were invested, as a priority, in areas with the poorest sanitation conditions and the environmental and health impacts were monitored by the Program. Results show that the prevalence of diarrhea fell by $21 \%$ ( $95 \% \mathrm{CI}$ : $18 \%-25 \%$ ), from 9.2 days per child-year before the intervention (95\%CI: 9.0-9.5), to 7.3 (95\%CI: 7.0-7.5) days per child-year after program completion. After adjustment for baseline sewer coverage and potential confounding variables, the overall reduction in prevalence was $22 \%$ (95\% CI: $19 \%-26 \%$ ) 7 .

Although a number of studies have focused on the formulation of indicators of intra-urban differentials 13 , a need for further research to assess intra-urban environmental quality associated with sanitation conditions has been highlighted 13,14

No similar approaches to defining environmental indicators were found in the literature. The environmental indicators described by this study allow intra-urban differentials to be detected with the use of primary data, thus facilitating the assessment of the impacts of sanitation programs in medium-sized cities. This study has the following specific objectives: (a) formulate environmental sanitation indicators; (b) identify the distinguishing variable for each environmental sanitation component; (c) classify sanitation conditions in intra-urban areas; (d) identify priority areas for intervention and resource allocation. 


\section{Materials and methods}

Located in the Northeastern region of Brazil, Salvador is the capital of the State of Bahia. Its 2.6 million inhabitants are exposed to health problems that are typical of large metropolitan areas. It is likely that the improvement in water supply made in the 1980s and 1990s (by 1997 over $90 \%$ of the city's households had access to piped water) had an effect on early childhood diarrhea (children up three years of age); however baseline data for the period before these improvements were made does not exist. A longitudinal study carried out in 1997 showed that the prevalence of childhood diarrhea was 9.2 days per childyear 7 . Before 1997 approximately $26 \%$ of households were connected to a safe sewer system, while the remaining population used sanitary alternatives (such as septic tanks) or unsanitary methods (such as discharging their sewage into the street). As a result, a large scale sanitation program called Bahia Azul ("Blue Bay") was initiated in 1997 with the goal of increasing the proportion of the population connected to an adequate sewer system from $26 \%$ to $80 \%$.

The original goal of the sanitation project was to control marine pollution largely caused by the discharge of domestic wastewater into the ocean. Around half of the total budget of US $\$ 440$ million, funded mainly by the Inter-American Development Bank, was earmarked for extending the sewer network in Salvador and ten smaller towns in the State of Bahia. Investments were also made in improvements to water supply and solid waste management and in institutional capacity building. Construction work was executed by 140 different construction companies and the largest contract amounted to $20 \%$ of the total budget. In Salvador, the construction works were carried out over a period of eight years (between 1996 and 2004) and consisted of more than $2,000 \mathrm{~km}$ of sewer pipes and 86 pumping stations, and the connection of more than 300,000 households to the sewer network. Heavy engineering work, such as laying sewer pipes and building pumping stations, was undertaken during the initial phase of the project. Since household connections were made during a later phase, very few connections to the sewer system were made before the end of the first cohort study.

An evaluation study consisting of two longitudinal studies 7 was conducted to assess the epidemiological impact of the program. Study and design and sampling have been described in detail by other authors 7,15,16.

Ethical approval was granted by the Research Ethics Committee of the Institute of Collective Health of the Federal University of Bahia (ISC/
UFBA). Written informed consent was obtained from study participants.

A separate study comprising of two crosssectional investigations was conducted to evaluate the environmental impact of the intervention. Environmental research was conducted in three stages. The first stage consisted of a survey of 1,225 street sections between September 1997 and February 1998 before the beginning of the Bahia Azul Program. The second stage included 973 street sections and was carried out between August 2000 and January 2001 during the implementation of the program. The third phase included 1,070 street sections and was performed between October 2003 and March 2004 after completion of the program.

Description of the environmental sanitation components and study variables

The environmental assessment of basic sanitation components in the study areas was carried out between August 2000 and January 2001. The unit of analysis was the "street section" where the children enrolled in the epidemiological study lived, which consisted of a $100 \mathrm{~m}$ long street section in front of the children's homes. A total of 973 street sections were visited. Information on infrastructure, the sanitation system, land use and building typology was collected for each street section 15. Data collection methods and the procedures followed to ensure quality of fieldwork are described in detail by Rego et al. 15 .

This study uses data from the Epidemiological Impact Assessment of the Bahia Azul Program (PAIE-BA) collected in 2000 by ISC/UFBA. The database contains information on environmental sanitation components by street section in eight sewerage basins and 23 neighborhoods.

The street sections were identified and grouped according to their sanitation components (water supply, sewer system, urban drainage, road pavement, public cleaning services and building typology). The environmental sanitation components and the respective variables and categories are described in Table 1. The categories include a reference category (RC) defined by the researchers as the most desirable condition for each variable.

\section{Statistical technique}

Cluster analysis was used to analyze data. This technique is commonly used to group similar elements or entities according to a set of variables using a matrix of $\mathrm{n}$ cases or elements (matrix rows) and p variables (matrix columns) that represent the characteristics of the elements chosen 
Table 1

Environmental sanitation components and variables assessed in the street sections. Salvador, Bahia State, Brazil, 2000.

\begin{tabular}{|c|c|c|}
\hline Components & Variables & Categories \\
\hline \multirow[t]{7}{*}{ Water supply } & Type of supply & Partially public network (presence of water well and/or gato * and/or public tap) \\
\hline & & Exclusively public network (RC) \\
\hline & Condition of network & Network with problems \\
\hline & & Network with no problems, in apparently good condition (RC) \\
\hline & Frequency of service & 3 to 4 times a week \\
\hline & & Everyday \\
\hline & & 24 hours a day $(R C)$ \\
\hline \multirow[t]{16}{*}{ Drainage system } & Stormwater runoff & Risk occurrence (more than one risk: stormwater floods the street, some or all homes; floods \\
\hline & & part of the street and some homes; floods only the street; presence of puddles and holes in the \\
\hline & & street, risk of landslides) \\
\hline & & No risk occurrence $(\mathrm{RC})$ \\
\hline & Type of drainage system & Non-existent \\
\hline & & Concrete cascade drain or other \\
\hline & & Storm sewer \\
\hline & & Channel and gutter (RC) \\
\hline & Condition of Drainage system & Non-existent \\
\hline & & Network with problems (more than one risk: stormwater floods the street, some or all homes; \\
\hline & & floods part of the street and some homes; floods only the street; presence of puddles and holes \\
\hline & & in the street, risk of landslides) \\
\hline & & Network with no problems and in apparently good condition (RC) \\
\hline & Existence/operation & Non-existent \\
\hline & & Network out-of-service \\
\hline & & Network operating (Bahia Azul and others) (RC) \\
\hline \multirow[t]{12}{*}{ Sewer system } & Status of sewer & Non-existent \\
\hline & & Another network other than the Bahia Azul \\
\hline & & Another network other than the Bahia Azul + Bahia Azul network \\
\hline & & Only Bahia Azul network (RC) \\
\hline & Condition of sewer & Non-existent \\
\hline & & Network with problems \\
\hline & & Network in apparently good condition (RC) \\
\hline & Operational condition of sewer & Non-existent \\
\hline & & Bahia Azul network out-of-service \\
\hline & & Network operating (Bahia Azul and others) (RC) \\
\hline & Condition of Manholes & Manholes non-existent and/or manholes with problems \\
\hline & & Manholes in apparently good condition (RC) \\
\hline Urban cleaning & Collection type & Non-existent \\
\hline \multirow[t]{9}{*}{ service } & & Stationary collecting points and/or dumpers \\
\hline & & Door-to-door/garbage truck/compactor/alternative (RC) \\
\hline & Collection frequency & Non-existent \\
\hline & & Existent, but irregular \\
\hline & & Daily collection (RC) \\
\hline & Existence of garbage point & Existent \\
\hline & & Non-existent (RC) \\
\hline & Existence of debris point & Existent \\
\hline & & Non-existent (RC) \\
\hline
\end{tabular}

(continues) 


\begin{tabular}{|c|c|c|}
\hline Components & Variables & Categories \\
\hline \multirow[t]{9}{*}{ Building typology } & Housing type & Horizontal 1 floor \\
\hline & & Horizontal 1 and/or 2 or more floors \\
\hline & & Vertical low and high template and combinations (RC) \\
\hline & Type of construction & Precarious (mud, wood, clay, straw, stilt homes and homes with or without brick/block structure) \\
\hline & & Intermediate (plastered brick/block structure, with partial coating, pre-fabricated) \\
\hline & & Good (brick/block plastered with coating) (RC) \\
\hline & Type of occupation & At the bottom of a hill \\
\hline & & On a slope \\
\hline & & On a plateau/ridge $(\mathrm{RC})$ \\
\hline \multirow[t]{6}{*}{ Paving } & Road pavement typology & Inadequate (gravel, earth, soil, sand or a combination) \\
\hline & & Adequate (cement or concrete surface, cobbles, mortar, cement) \\
\hline & & More appropriate (asphalt and paving stones) (RC) \\
\hline & Type of sidewalk & Inadequate (non-existent, unpaved) \\
\hline & & Partially adequate (dusty track, sand or a combination) \\
\hline & & Adequate (cement or concrete surface, cobbles, gravel, Portuguese stone, asphalt, granite) (RC) \\
\hline
\end{tabular}

RC: reference category.

* Gato is a popular term meaning an illegal unpaid connection to the water supply service.

to measure level of similarity. Level of similarity is based on the distance between the elements; if the distance between two elements is zero they are considered identical and belong to the same category. A commonly used measure of similarity is the Euclidean distance ${ }^{17}$. This measure was used by this study to determine the distance between pairs of street sections for six environmental sanitation components, each with a specific number of variables. For example, for a component made up of three binary variables $\mathrm{X}_{1}, \mathrm{X}_{2}$ and $\mathrm{X}_{3}$, the average Euclidian distance between the street sections A and B is calculated using the following equation:

$\mathrm{d}(\mathrm{A}, \mathrm{B})=\left[\frac{1}{p} \sum_{i=1}^{p}\left(X_{i}(A)-X_{i}(B)\right)^{2}\right]$

where $p$ is the number of variables ( $p=3$ in this case) and $d(A, B)$ is a real number. The distance between pairs of elements is usually expressed as an $\mathrm{n} \times \mathrm{n}$ symmetric matrix.

When a variable has more than two categories the usual procedure is to transform these variables into binary variables by creating fictitious variables 17 . Thus, three binary variables are needed to represent a variable with three categories.

The average linkage method was used to group the distances between street sections. The results of the cluster analysis are generally represented in a tree-like diagram called a dendrogram. Genuine cluster groups are identified by "cutting" the dendrogram at a certain level subjectively chosen by visual examination 17 .

\section{Data analysis}

Initially, a descriptive and exploratory analysis of the dataset was performed for each variable shown in Table 1. Cluster analysis was used to group and classify the sewer basins and neighborhoods. Indicators were formulated by completing the following steps during analysis: (1) transformation of variables; (2) clustering of street sections; (3) identification of the distinguishing variable for each component; (4) classification of sanitation conditions in the sewer basins and neighborhoods by component; and (5) general classification of sanitation conditions in the sewer basins and neighborhoods.

In step one, the variables that had more than two categories were transformed into binary variables. For example, the variable frequency of service has three categories (three to four times a week, everyday, and 24 hours a day). Each category was converted into a binary variable in which the value one (1) means that the characteristic is present and the value zero (0) means that the characteristic is absent 17. For example, let $\mathrm{X}_{3}, \mathrm{X}_{4}$ and $\mathrm{X}_{5}$ represent three to four times a week, everyday and 24 hours a day, respectively. In the case that the frequency of water supply in street A is 24 hours a day, $X_{3}=0, X_{4}=0, X_{5}=1$.

In step two, cluster analysis was used to group the 973 street sections according to each environmental sanitation component by neighborhood and basin. For instance, the variables type of supply $\left(\mathrm{X}_{1}\right)$, general condition of the network $\left(\mathrm{X}_{2}\right)$, and frequency of service, the latter men- 
tioned above and reclassified into three binary variables $\left(\mathrm{X}_{3}, \mathrm{X}_{4}\right.$ and $\left.\mathrm{X}_{5}\right)$, were used to group the 973 street sections according to the water supply component. Equation 1 was used to calculate the distances between pairs of street sections considering the five variables $\mathrm{X}_{1}, \mathrm{X}_{2}, \mathrm{X}_{3}, \mathrm{X}_{4}$ and $\mathrm{X}_{5}$ $(p=5)$ and the average linkage method was used to group these distances into three categories (1, 2 and 3). The SPSS version 13.0 software was used for statistical analysis (SPSS Inc., Chicago, USA).

In step three, each resulting cluster (1,2 and 3 ) was identified according to its main characteristic based on a descriptive analysis of each environmental sanitation component. Comparing the characteristics of the clusters (1,2 and 3) it was possible to note that the main difference was attributed to a single variable in each component. This variable was therefore considered the distinguishing variable for each component.

In step four a classification of neighborhoods and basins by component was produced based on the distinguished variable defined in step three. To this end, the reference cathegories shown in Table 1 were used. The sewer basins and neighborhoods were classified based on the percentage of street sections with the given characteristic as follows: 0 to $33.3 \%=$ poor; 33.4 to $66.6 \%=$ regular; 66.7 to $100 \%=$ good .

These classification criteria were employed since they were considered to be the most objective, coherent and accessible.

In step 5, an overall classification of sanitation conditions in the sewer basins and neighborhoods was carried out based on the average percentage of all sanitation components as follows: 0 to $33.3 \%$ = poor; 33.4 to $66.6 \%=$ regular; 66.7 to $100 \%=$ good.

\section{Results}

Table 2 shows the results of the cluster analysis carried out in step 2 for the water supply component. It can be observed that in the Armação and Paripe Basins 73 (78.5\%) and 5 (4\%) of the street sections, respectively, were classified as cluster 2, showing heterogeneity between sewer basins.

Table 3 shows the main characteristics of the environmental sanitation components for each cluster. With respect to water supply, $92.1 \%$ of street sections $(n=429)$ in cluster 1 benefited from an exclusively public network, in $72.7 \%$ of sections the network had no problems and were in apparently good condition, and in $100 \%$ of sections the frequency of the service was every day. In cluster 2, 95.5\% of street sections $(n=330)$ benefited from an exclusively public network, in $81.2 \%$ of sections the network had no problems and was in apparently in good condition, and in $100 \%$ of sections the frequency of service was 24 hours a day. Finally, in cluster 3, 79.9\% of street sections $(n=214)$ benefited from an exclusively public network, in $64 \%$ of sections the network had no problems and was in apparently good condition, and in $100 \%$ of sections the frequency of service was three to four times a week. A comparison of the characteristics of the clusters shows that the main difference was due to the variable frequency of service. It can therefore be concluded that frequency of service is the key variable that explains the difference between clusters for the water supply component. In other words, the variable frequency of service is the key variable that discriminates between clusters.

The sewer basins and neighborhoods were classified as poor, regular and good based on the percentage of street sections receiving water 24 hours a day (reference category); thus, the street sections in each cluster were labeled as follows: cluster 1 = "water every day"; cluster 2 = "water 24 hours a day"; and cluster 3 = "water three to four times a week".

Table 3 summarizes the results of the cluster analysis for all components, from which it is possible to identify the distinguishing variable for each component and main characteristic. With regard to water supply, frequency of service stood out in the statistical analysis as the key variable and the reference category was a 24-hour a day water supply.

Table 4 presents the results of the classification of the sewer basins and neighborhoods in Salvador using the steps described above. It can be observed that the best ranked sewer basin was the Armação Basin, where $71 \%$ of street sections were classified as having good services. Service provision was classified as regular in the Médio Camurujipe, Lobato and Calafate sewer basins, where 34.7 to $43.2 \%$ of street sections were classified as having good services. In the Mangabeira, Cobre, Periperi and Paripe sewer basins service provision was classified as poor with around only $27 \%$ of street sections being classified as having good services.

With respect to individual neighborhoods, Table 4 shows that service provision was classified as good in areas 571 and 575 since $71 \%$ of street sections had good services. In areas $322,327,330$, 208, 204, 263, 323 and 961 service provision was considered regular, whereas areas 118, 205, 672, 677, 678, 191, 962, 1011, 1025, 1026, 1054, 1057 and 1072 were classified as poor.

Table 4 allows the comparison of sewer basins and neighborhoods by component. In the 
Table 2

Classification of basins and neighborhoods according to the results of the cluster analysis for the water supply component.

\begin{tabular}{|c|c|c|c|c|c|c|c|}
\hline \multirow[t]{3}{*}{ Neighborhoods/Basins } & \multicolumn{6}{|c|}{ Water supply cluster } & \multirow{3}{*}{$\begin{array}{c}\text { Total of } \\
\text { street } \\
\text { sections }\end{array}$} \\
\hline & \multicolumn{2}{|c|}{1} & \multicolumn{2}{|c|}{2} & \multicolumn{2}{|c|}{3} & \\
\hline & $\mathrm{n}$ & $\%$ & $n$ & $\%$ & $\mathrm{n}$ & $\%$ & \\
\hline \multicolumn{8}{|l|}{ Armação } \\
\hline 571 & 10 & 12.8 & 66 & 84.6 & 2 & 2.6 & 78 \\
\hline 575 & 1 & 6.7 & 7 & 46.7 & 7 & 46.7 & 15 \\
\hline Total & 11 & 11.8 & 73 & 78.5 & 9 & 9.7 & 93 \\
\hline \multicolumn{8}{|l|}{ Médio Camurujipe } \\
\hline 322 & 30 & 48.4 & 31 & 50.0 & 1 & 1.6 & 62 \\
\hline 327 & 19 & 32.2 & 39 & 66.1 & 1 & 1.7 & 59 \\
\hline 330 & 30 & 57.7 & 18 & 34.6 & 4 & 7.7 & 52 \\
\hline Total & 79 & 45.7 & 88 & 50.9 & 6 & 3.5 & 173 \\
\hline \multicolumn{8}{|l|}{ Lobato } \\
\hline 118 & 9 & 52.9 & 4 & 23.5 & 4 & 23.5 & 17 \\
\hline 205 & 19 & 57.6 & 8 & 24.2 & 6 & 18.2 & 33 \\
\hline 208 & 10 & 20.8 & 35 & 72.9 & 3 & 6.3 & 48 \\
\hline Total & 38 & 38.8 & 47 & 48.0 & 13 & 13.3 & 98 \\
\hline \multicolumn{8}{|l|}{ Calafate } \\
\hline 204 & 20 & 43.5 & 25 & 54.3 & 1 & 2.2 & 46 \\
\hline 263 & 21 & 58.3 & 15 & 41.7 & 0 & 0.0 & 36 \\
\hline 323 & 22 & 50.0 & 16 & 36.4 & 6 & 13.6 & 44 \\
\hline Total & 63 & 50.0 & 56 & 44.4 & 7 & 5.6 & 126 \\
\hline \multicolumn{8}{|l|}{ Mangabeira } \\
\hline 672 & 31 & 55.4 & 20 & 35.7 & 5 & 8.9 & 56 \\
\hline 677 & 25 & 62.5 & 10 & 25.0 & 5 & 12.5 & 40 \\
\hline 678 & 28 & 60.9 & 13 & 28.3 & 5 & 10.9 & 46 \\
\hline Total & 84 & 59.2 & 43 & 30.3 & 15 & 10.6 & 142 \\
\hline \multicolumn{8}{|l|}{ Cobre } \\
\hline 191 & 18 & 78.3 & 0 & 0.0 & 5 & 21.7 & 23 \\
\hline 961 & 11 & 47.8 & 0 & 0.0 & 12 & 52.2 & 23 \\
\hline 962 & 20 & 40.4 & 10 & 22.2 & 15 & 33.3 & 45 \\
\hline Total & 49 & 53.8 & 10 & 11.0 & 35 & 35.2 & 91 \\
\hline \multicolumn{8}{|l|}{ Periperi } \\
\hline 1011 & 34 & 58.6 & 3 & 5.2 & 21 & 36.2 & 58 \\
\hline 1025 & 9 & 25.0 & 5 & 13.9 & 22 & 61.1 & 36 \\
\hline 1026 & 10 & 33.3 & 0 & 0.0 & 21 & 66.7 & 30 \\
\hline Total & 53 & 42.7 & 8 & 6.5 & 63 & 50.8 & 124 \\
\hline \multicolumn{8}{|l|}{ Paripe } \\
\hline 1054 & 18 & 39.1 & 0 & 0.0 & 28 & 60.9 & 46 \\
\hline 1057 & 30 & 62.5 & 5 & 10.4 & 13 & 27.1 & 48 \\
\hline 1072 & 4 & 12.5 & 0 & 0.0 & 28 & 87.5 & 32 \\
\hline Total & 52 & 41.3 & 5 & 4.0 & 69 & 54.8 & 126 \\
\hline $\begin{array}{l}\text { Total number of street } \\
\text { sections }\end{array}$ & 429 & & 330 & & 214 & & 973 \\
\hline
\end{tabular}


Table 3

Main characteristics of environmental sanitation components by cluster.

\begin{tabular}{|c|c|c|c|c|c|c|c|}
\hline & Cluster & $\mathrm{n}$ & $\%$ & Variables & $\mathrm{n}$ & $\%$ & Main characteristics \\
\hline \multirow[t]{9}{*}{ Water supply } & 1 & 429 & 44.1 & Type of supply & 395 & 92.1 & Exclusively public network \\
\hline & & & & Condition of network & 312 & 72.7 & $\begin{array}{l}\text { Network with no problems and in } \\
\text { apparently good condition }\end{array}$ \\
\hline & & & & Frequency of service & 429 & 100.0 & Everyday \\
\hline & 2 & 330 & 33.9 & Type of supply & 315 & 95.5 & Exclusively public network \\
\hline & & & & Condition of network & 268 & 81.2 & $\begin{array}{l}\text { Network with no problems and in } \\
\text { apparently good condition }\end{array}$ \\
\hline & & & & Frequency of service & 330 & 100.0 & 24 hours a day \\
\hline & 3 & 214 & 22.0 & Type of supply & 171 & 79.9 & Exclusive public network \\
\hline & & & & Condition of network & 137 & 64.0 & $\begin{array}{l}\text { Network with no problems and in apparently } \\
\text { good condition }\end{array}$ \\
\hline & & & & Frequency of service & 214 & 100.0 & 3 to 4 times a week \\
\hline Drainage & 1 & 356 & 33.6 & Stormwater runoff & 236 & 66.3 & No risk \\
\hline \multirow[t]{11}{*}{ system } & & & & Type of drainage system & 215 & 60.4 & Storm sewer \\
\hline & & & & Condition of drainage system & 182 & 51.1 & $\begin{array}{l}\text { Network with no problems and in apparently } \\
\text { good condition }\end{array}$ \\
\hline & & & & Existence/Operation & 356 & 100.0 & Network in operation \\
\hline & 2 & 600 & 61.7 & Stormwater runoff & 311 & 51.8 & No risk \\
\hline & & & & Type of drainage system & 600 & 100.0 & Non-existent \\
\hline & & & & Condition of drainage system & 600 & 100.0 & Non-existent \\
\hline & & & & Existence/Operation & 600 & 100.0 & Non-existent \\
\hline & 3 & 17 & 1.7 & Stormwater runoff & 10 & 58.8 & No risk \\
\hline & & & & Type of drainage system & 11 & 64.7 & Storm sewer \\
\hline & & & & Condition of drainage system & 13 & 76.5 & Network with no problems \\
\hline & & & & Existence/Operation & 17 & 100.0 & Network out-of-service \\
\hline Sewerage & 1 & 403 & 41.4 & Status of sewer & 185 & 45.9 & Another network other than the Bahia Azul \\
\hline \multirow[t]{11}{*}{ system } & & & & Condition of sewer & 324 & 80.4 & Network in apparently good condition \\
\hline & & & & Operational condition of sewer & 403 & 100.0 & Network in operation (Bahia Azul and others) \\
\hline & & & & Condition of Manholes & 309 & 76.7 & $\begin{array}{l}\text { Manholes non-existent and Manholes } \\
\text { with problems }\end{array}$ \\
\hline & 2 & 269 & 27.6 & Status of sewer & 269 & 100.0 & Non-existent \\
\hline & & & & Condition of sewer & 269 & 100.0 & Non-existent \\
\hline & & & & $\begin{array}{l}\text { Operational condition } \\
\text { of sewerage }\end{array}$ & 269 & 100.0 & Non-existent \\
\hline & & & & Condition of Manholes & 269 & 100.0 & Non-existent \\
\hline & 3 & 301 & 30.9 & Status of sewer & 289 & 96.0 & $\begin{array}{l}\text { Another network other than Bahia Azul + } \\
\text { Bahia Azul network }\end{array}$ \\
\hline & & & & Condition of sewer & 254 & 84.4 & Network in apparently good condition \\
\hline & & & & Operational condition of sewer & 301 & 100.0 & Bahia Azul network out-of-service \\
\hline & & & & Condition of manholes & 207 & 68.8 & $\begin{array}{l}\text { Manholes non-existent and Manholes } \\
\text { with problems }\end{array}$ \\
\hline
\end{tabular}

(continues)

Armação Basin, for example, the classification of neighborhoods by water supply is variable; service provision in neighborhood 571 is classified as good (water supply is 24-hour a day in $84.6 \%$ of street sections ), while in neighborhood 575 it is considered regular (water supply is 24-hour a day in only $46.7 \%$ of street sections).

It is interesting to note that the worst results in terms of percentages were obtained for the paving and housing typology components, while 


\begin{tabular}{|c|c|c|c|c|c|c|c|}
\hline & Cluster & $\mathrm{n}$ & $\%$ & Variables & n & $\%$ & Main characteristics \\
\hline \multirow{12}{*}{$\begin{array}{l}\text { Urban } \\
\text { cleaning } \\
\text { service }\end{array}$} & 1 & 425 & 43.7 & Collection type & 425 & 100.0 & $\begin{array}{c}\text { Door-to-door/garbage truck/compactor/ } \\
\text { alternative }\end{array}$ \\
\hline & & & & Collection frequency & 240 & 56.5 & Daily collection \\
\hline & & & & Existence of garbage point & 344 & 80.9 & Non-existent \\
\hline & & & & Existence of debris point & 335 & 78.8 & Non-existent \\
\hline & 2 & 108 & 11.1 & Collection type & 108 & 100.0 & Stationary collection points and/or Dumpers \\
\hline & & & & Collection frequency & 70 & 64.8 & Daily collection \\
\hline & & & & Existence of garbage point & 72 & 66.7 & Existent \\
\hline & & & & Existence of debris point & 73 & 67.6 & Non-existent \\
\hline & 3 & 440 & 45.2 & Collection type & 440 & 100.0 & Non-existent \\
\hline & & & & Collection frequency & 440 & 100.0 & Non-existent \\
\hline & & & & Existence of garbage point & 349 & 79.3 & Non-existent \\
\hline & & & & Existence of debris point & 320 & 72.7 & Non-existent \\
\hline \multirow{9}{*}{$\begin{array}{l}\text { Housing } \\
\text { typology }\end{array}$} & 1 & 361 & 37.1 & Type of housing & 264 & 73.1 & Horizontal 1 and/or 2 or more floors \\
\hline & & & & Type of construction & 244 & 67.6 & Intermediate \\
\hline & & & & Type of occupation & 361 & 100.0 & At the bottom of a hill \\
\hline & 2 & 269 & 27.6 & Type of housing & 188 & 69.9 & Horizontal 1 and/or 2 or more floors \\
\hline & & & & Type of construction & 169 & 62.8 & Intermediate \\
\hline & & & & Type of occupation & 269 & 100.0 & On a plateau/ridge \\
\hline & 3 & 343 & 35.3 & Type of housing & 248 & 72.3 & Horizontal 1 and/or 2 or more floors \\
\hline & & & & Type of construction & 288 & 84.0 & Intermediate \\
\hline & & & & Type of occupation & 343 & 100.0 & On a slope \\
\hline \multirow[t]{6}{*}{ Paving } & 1 & 246 & 25.3 & Road pavement typology & 195 & 79.3 & More appropriate \\
\hline & & & & Type of sidewalk & 246 & 100.0 & Adequate \\
\hline & 2 & 67 & 6.9 & Road pavement typology & 58 & 86.6 & More appropriate \\
\hline & & & & Type of sidewalk & 67 & 100.0 & Partially adequate \\
\hline & 3 & 660 & 67.8 & Road pavement typology & 401 & 60.8 & Inadequate \\
\hline & & & & Type of sidewalk & 660 & 100.0 & Inadequate \\
\hline
\end{tabular}

the best results were obtained for urban cleaning. This example shows the utility of the methodology used by this study for prioritizing government investment in sanitation.

\section{Discussion and conclusion}

Through the use of cluster analysis it was possible to formulate environmental sanitation indicators, classify sanitation conditions in specific sewer basins and their respective neighborhoods, and detect intra-urban differentials in sanitation conditions. This method is particularly useful for assessing the impact of sanitation programs in medium-sized cities such as the Bahia Azul Program 7,10. Furthermore, this method allows the comparison of sanitation conditions in sewer basins and neighborhoods in different moments in time. By using environmental sanitation indicators it was possible to identify priority areas for interventions and allocation of resources. It is important to emphasize that this is a low cost and simple methodology and is therefore a key decision-making support for politicians and environmental health managers.

Furthermore, based on the results of this study, it is possible to infer that if more resources had been invested in all environmental sanitation components in those sewer basins with the worst indicators (Mangabeira, Cobre, Periperi and Paripe) it is likely that the diarrhea prevalence rate observed by Barreto et al. 7 would have been lower. The results show that all components in these basins were classified as poor, except urban cleaning which was considered regular.

Cluster analysis also allowed us to identify the variable that best distinguished between the environmental sanitation components, thus helping to reduce the number of variables in the study and indicate the key variable for each component. 
Classification of neighborhoods and basins by component and general classification.

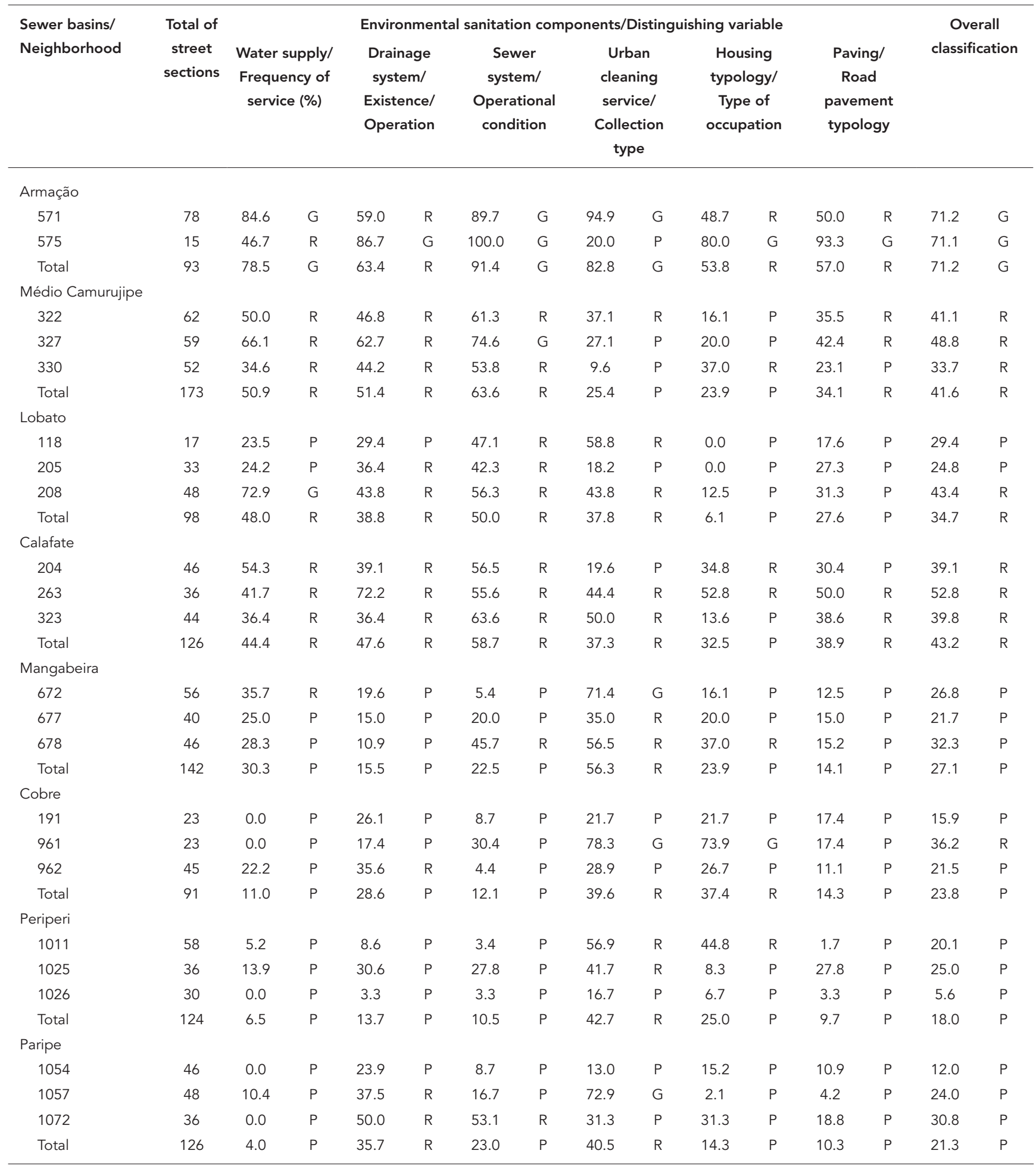

G: good; P: poor; R: regular. 
This methodology also allowed us to create an indicator for each environmental sanitation component and rank sewer basins and neighborhoods according to sanitation conditions.

As mentioned in the material and methods section above, a separate environmental impact assessment was conducted as part of the Epidemiological Impact Assessment of the Todos os Santos Bay Environmental Sanitation Program. This assessment was divided in three stages. The results of the first stage between September 1997 and February 1998 were published by Milroy et al. 18. Using the same data collection methods in the same neighborhoods covered by the present study, the authors used principal component analysis followed by cluster analysis to identify the following sanitation condition categories: high, intermediate, poor and very poor.

A comparison of the results of Milroy's study (first stage) 18 with those of the present study (second stage) shows that little change occurred in the classification of the sanitation conditions of these neighborhoods. The only change observed was in neighborhood 961, which was classified as poor in the first stage and as regular in the second stage. The improvements observed in this neighborhood were due to a high rating for the components "urban cleaning service" and "building typology" (Table 4). No change in the sanitation conditions of these neighborhoods was observed even after using other statistical methods. This is probably due to the fact that the Sanitation Program was in the initial phase of implementation at that time.
The environmental sanitation indicators formulated by this study can help managers to detect situations of environmental risk, monitor changes in the environment, identify potential health hazards and assess the impact of public policy interventions on environmental sanitation conditions.

The factors that influence environmental sanitation conditions are dynamic and therefore subject to constant change. The data collected by cross-sectional studies represents only one moment in time and therefore provides limited knowledge of a given reality. This method is therefore appropriate for assessing the impact of public policies and interventions on environmental sanitation conditions provided that further cross-sectional studies using the same methodology are conducted in the same areas in different windows of time.

The study data was analyzed using cluster analysis and Euclidian distance to measure the level of similarity. It is important to note that other types of distance may be used to measure the level of similarity, such as the simple correlation coefficient and Sokal distance, and it is recommended that future studies consider such approaches. Nevertheless, this study is an important step towards providing an effective classification of sanitation conditions in urban areas to guide resource allocation planning in developing countries. 


\section{Resumen}

Varias enfermedades que afectan a los seres humanos están vinculadas a la deficiencia en el acceso a servicios de agua y alcantarillado, la gestión inadecuada de los residuos sólidos y el deficiente sistema de drenaje de aguas pluviales. Este estudio trata de desarrollar indicadores de salud ambiental y clasificar las áreas dentro de las ciudades. Se utilizó una base de datos que contiene información sobre: limpieza urbana, abastecimiento de agua, alcantarillado, drenaje y calles, pavimentación de las calles y tipología de construcción en diferentes barrios. Se aplicó la técnica de clúster para el análisis de datos. Se identificó la variable que mejor representa cada componente y veintitrés áreas de la ciudad se clasificaron en tres categorías: buena, regular y mala. El uso de indicadores de salud ambiental permitió la identificación de áreas críticas y el establecimiento de prioridades en la inversión para la salud y mejora del medio ambiente.

Indicadores Ambientales; Saneamiento; Salud Ambiental

\section{Contributors}

R. F. Rego, M. L. Barreto, M. S. Prado and A. Strina contributed to study design and data collection. R. F. Rego, V. C. Lima and A. C. Lima carried out data analysis. All researchers contributed to data interpretation and drafting of the manuscript. All researchers had access to all study data and jointly agreed to submit this article for publication.

\section{Acknowledgments}

Financial support for this study was provided by PRONEX-FAPERJ,CNPq (grantnumber661086/1998-4), the Department of Infrastructure of the State of Bahia. R. F. R. F. Rego received a Graduate Thesis Grant in Public Health/PAHO (AMR00/074302-01) and support from the CNPq (grant number 140594/2000). We are grateful to these organizations for their financial support, to the fieldwork team and to the families that participated in the study.

\section{Conflict of interest}

The sponsors of this study had no role in the study design, data collection, data analysis, data interpretation, decision to publish or preparation of the manuscript. The authors had full access to all study data and jointly agreed to submit this article for publication.

\section{References}

1. Andreazzi MA, Barcellos C, Hacon S. Old indicators for new problems: the relationship between sanitation and health. Rev Panam Salud Pública 2007; 22:211-7.

2. Pruss-Ustun A, Corvalan C. How much disease burden can be prevented by environmental interventions? Epidemiology 2007; 18:167-78

3. United Nations. The Millennium Development Goals Report. http://mdgs.un.org/unsd/mdg/ Resources/Static/Products/Progress2010/MDG Report_2010_En_low\%20res.pdf (accessed on 05/ Jan/2012).

4. Instituto de Pesquisa Econômica Aplicada. Objetivos de desenvolvimento do milênio: 3 o Relatório Nacional de Acompanhamento. http://www.pnud org.br/Docs/3_RelatorioNacionalAcompanha mentoODM.pdf (accessed on 07/Jan/2012).
5. Ezzati M, Utzinger J, Cairncross S, Cohen AJ, Singer BH. Environmental risks in the developing world: exposure indicators for evaluating interventions, programmes, and policies. J Epidemiol Community Health 2005; 59:15-22.

6. Pruss-Ustun A, Bonjour S, Corvalan C. The impact of the environment on health by country: a metasynthesis. Environ Health 2008; 7:7.

7. Barreto ML, Genser B, Strina A, Teixeira MG, Assis AM, Rego RF, et al. Effect of city-wide sanitation programme on reduction in rate of childhood diarrhoea in northeast Brazil: assessment by two cohort studies. Lancet 2007; 370:1622-8.

8. Bhunia R, Ramakrishnan R, Hutin Y, Gupte MD. Cholera outbreak secondary to contaminated pipe water in an urban area, West Bengal, India, 2006 Indian J Gastroenterol 2009; 28:62-4 
9. Swain SK, Baral P, Hutin YJ, Rao TV, Murhekar M, Gupte MD. A hepatitis E outbreak caused by a temporary interruption in a municipal water treatment system, Baripada, Orissa, India, 2004. Trans R Soc Trop Med Hyg 2010; 104:66-9.

10. Barreto ML, Genser B, Strina A, Teixeira MG, Assis AM, Rego RF, et al. Impact of a citywide sanitation program in Northeast Brazil on intestinal parasites infection in young children. Environ Health Perspect 2010; 118:1637-42.

11. Farooqui A, Khan A, Kazmi SU. Investigation of a community outbreak of typhoid fever associated with drinking water. BMC Public Health 2009; 9:476.

12. Fewtrell L, Kaufmann RB, Kay D, Enanoria W, Haller L, Colford Jr. JM. Water, sanitation, and hygiene interventions to reduce diarrhoea in less developed countries: a systematic review and meta-analysis. Lancet Infect Dis 2005; 5:42-52.

13. Akerman M, Campanario P, Maia PB. Environment and health: an analysis of intra-urban differentials in the city of Sao Paulo, Brazil. Rev Saúde Pública 1996; 30:372-82.
14. Stephens C, Akerman M, Avle S, Maia PB, Campanario P, Doe B, et al. Urban equity and urban health: using existing data to understand inequalities in health and environment in Accra, Ghana and Sao Paulo, Brazil. Environ Urban 1997; 9:181-202.

15. Rego RF, Barreto ML, Santos R, Oliveira NF, Oliveira S. Rubbish index and diarrhoea in Salvador, Brazil. Trans R Soc Trop Med Hyg 2007; 101:722-9.

16. Teixeira MG, Barreto ML, Costa MCN, Strina A, Martins Jr. D, Prado M. Sentinel areas: a monitoring strategy in public health. Cad Saúde Pública 2002; 18:1189-95.

17. Johnson RA, Wichern DW. Applied multivariate statistical analysis. $5^{\text {th }}$ Ed. Upper Saddle River: Prentice Hall; 2002.

18. Milroy CA, Borja PC, Barros FR, Barreto ML. Evaluating sanitary quality and classifying urban sectors according to environmental conditions. Environment Urban 2001; 13:235-55.

Submitted on 12/Aug/2012

Final version resubmitted on 14/Jan/2013

Approved on 28/Jan/2013 